\title{
Radester, A Novel Inhibitor of the Hsp90 Protein Folding Machinery
}

\author{
Gang Shen and Brian S. J. Blagg*
}
Department of Medicinal Chemistry and the Center for Protein Structure and Function 1251 Wescoe Hall Drive, Malott 4070, The University of Kansas, Lawrence, KS 66045-7563
bblagg@,ku.edu

\section{Supplementary Information}

\author{
Spectra for Compounds
}



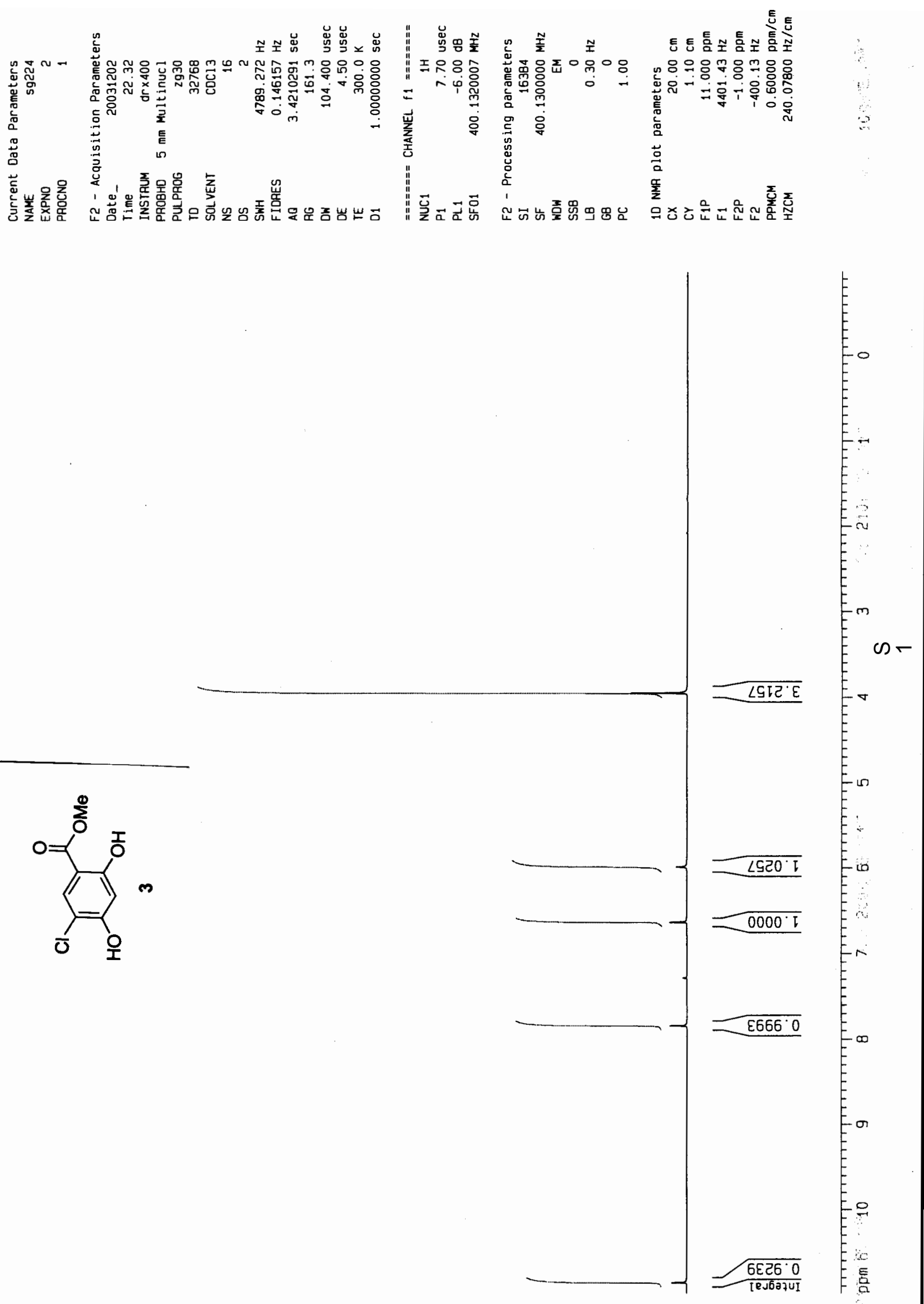

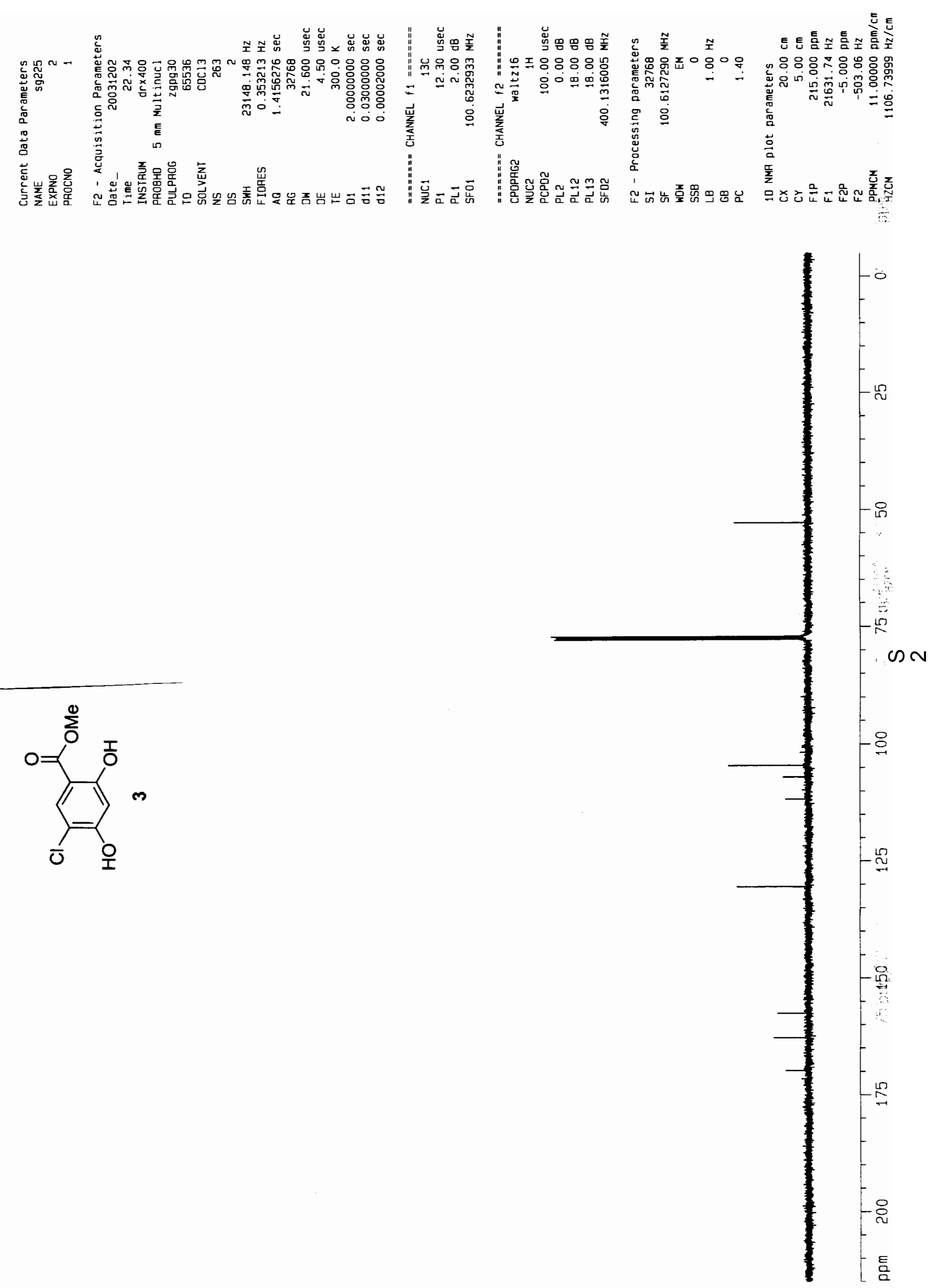

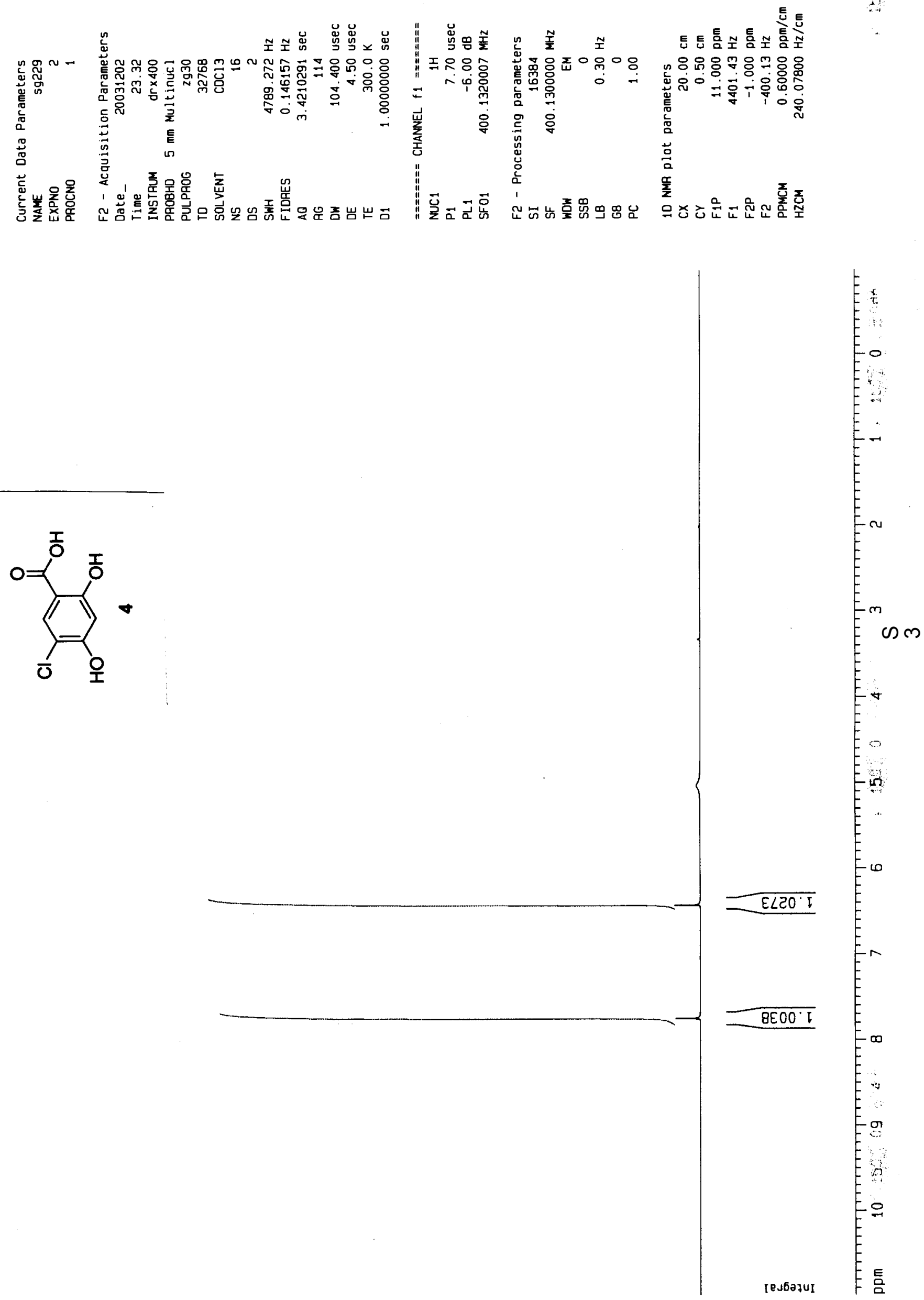


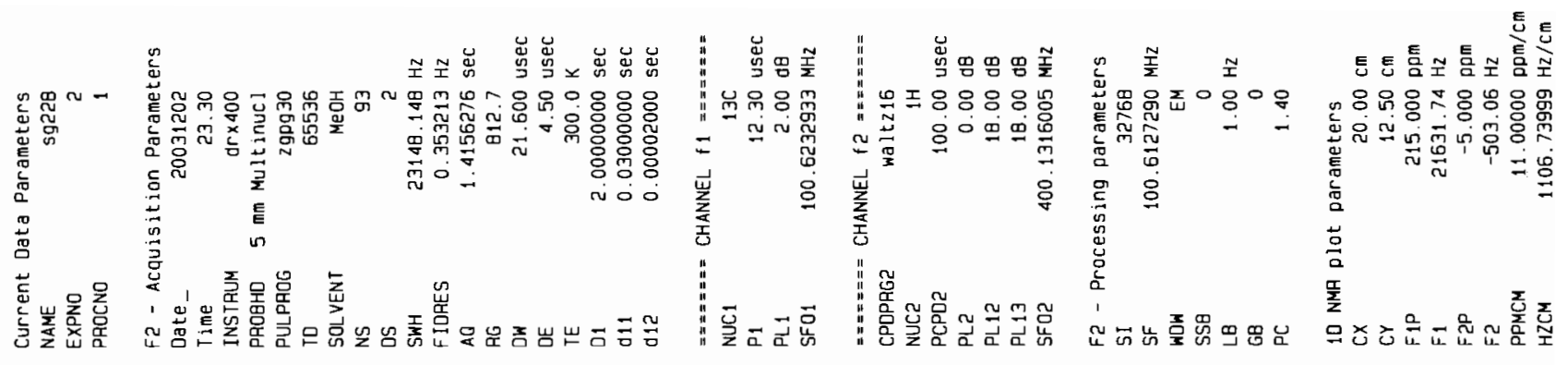

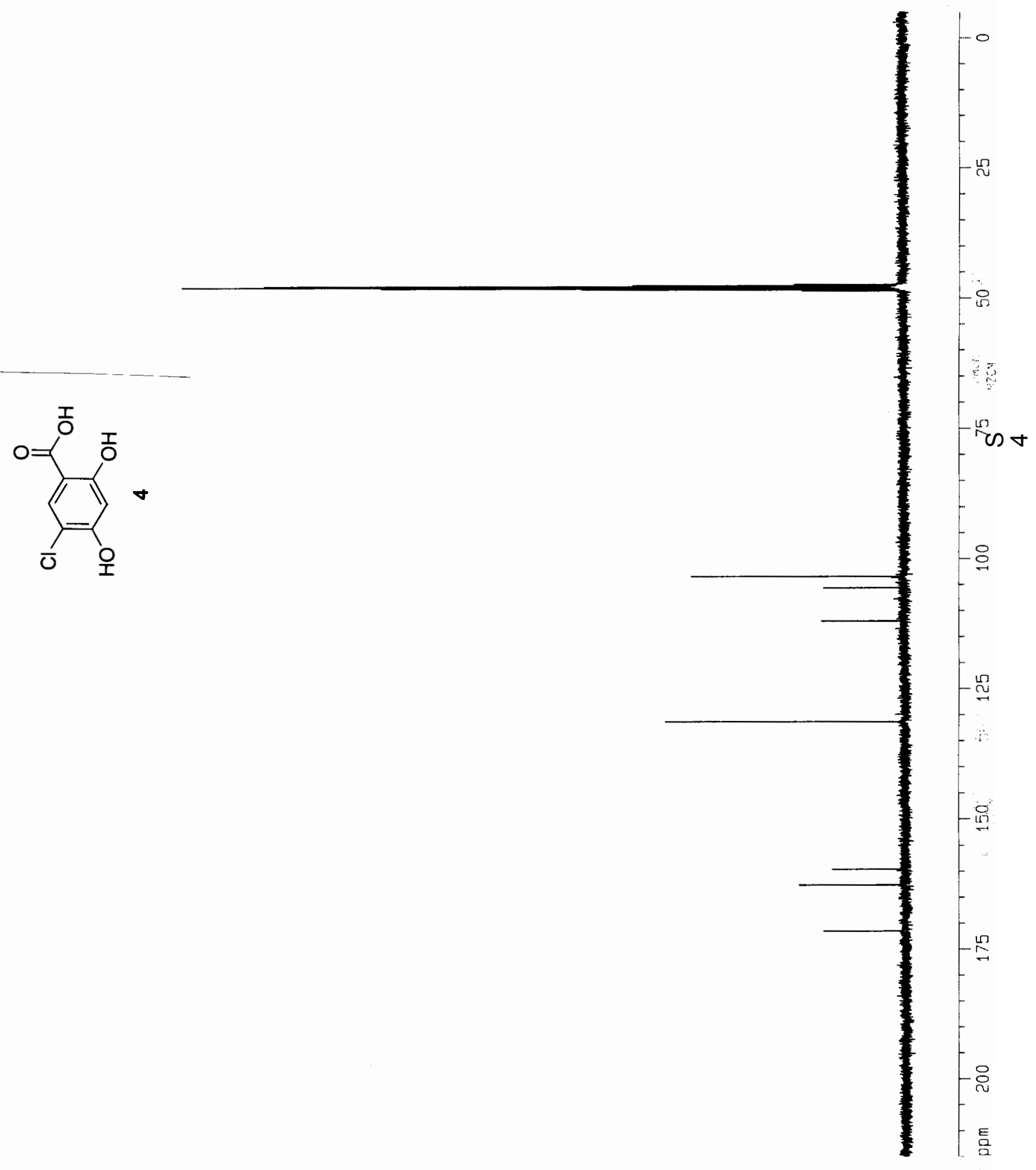



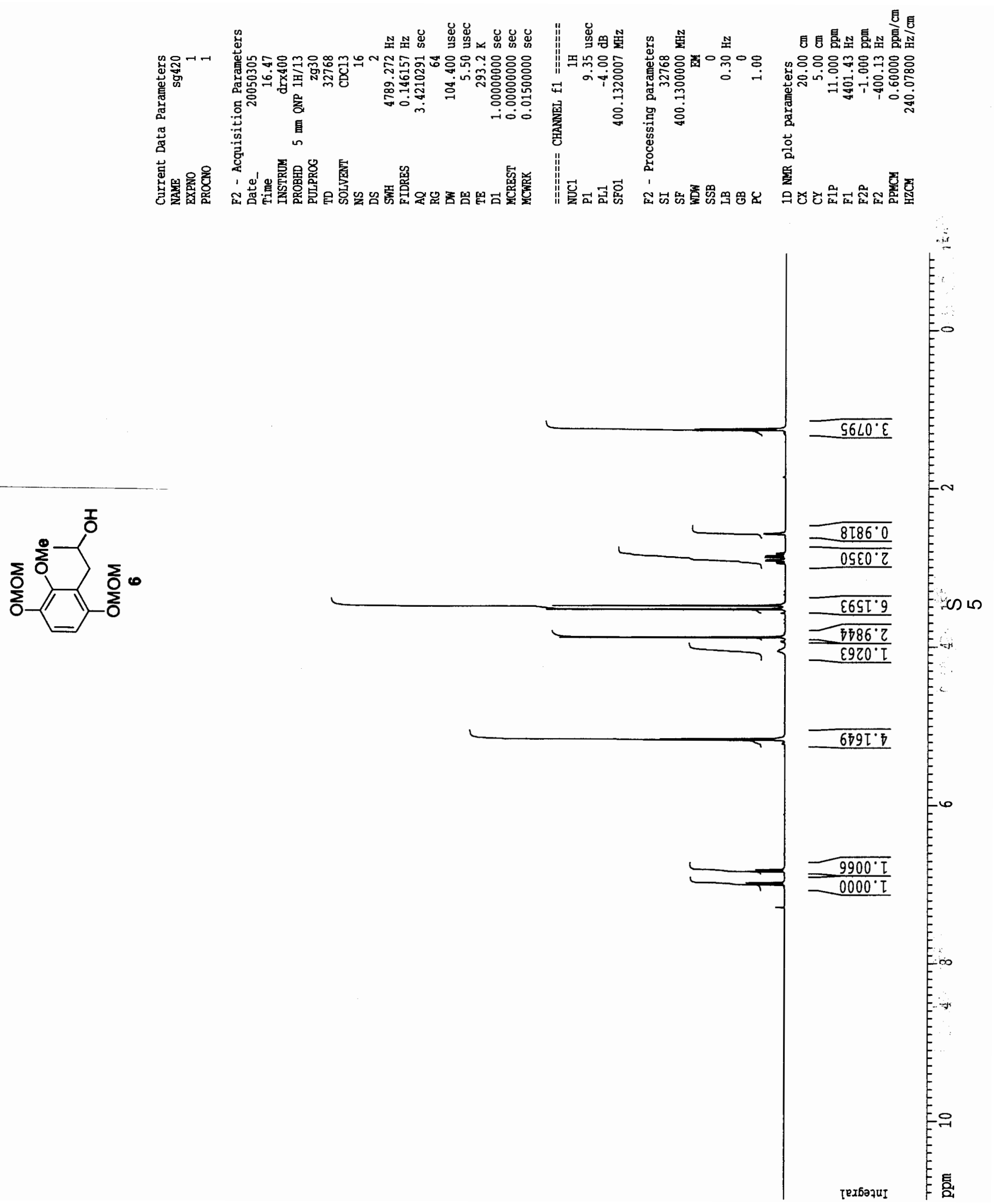

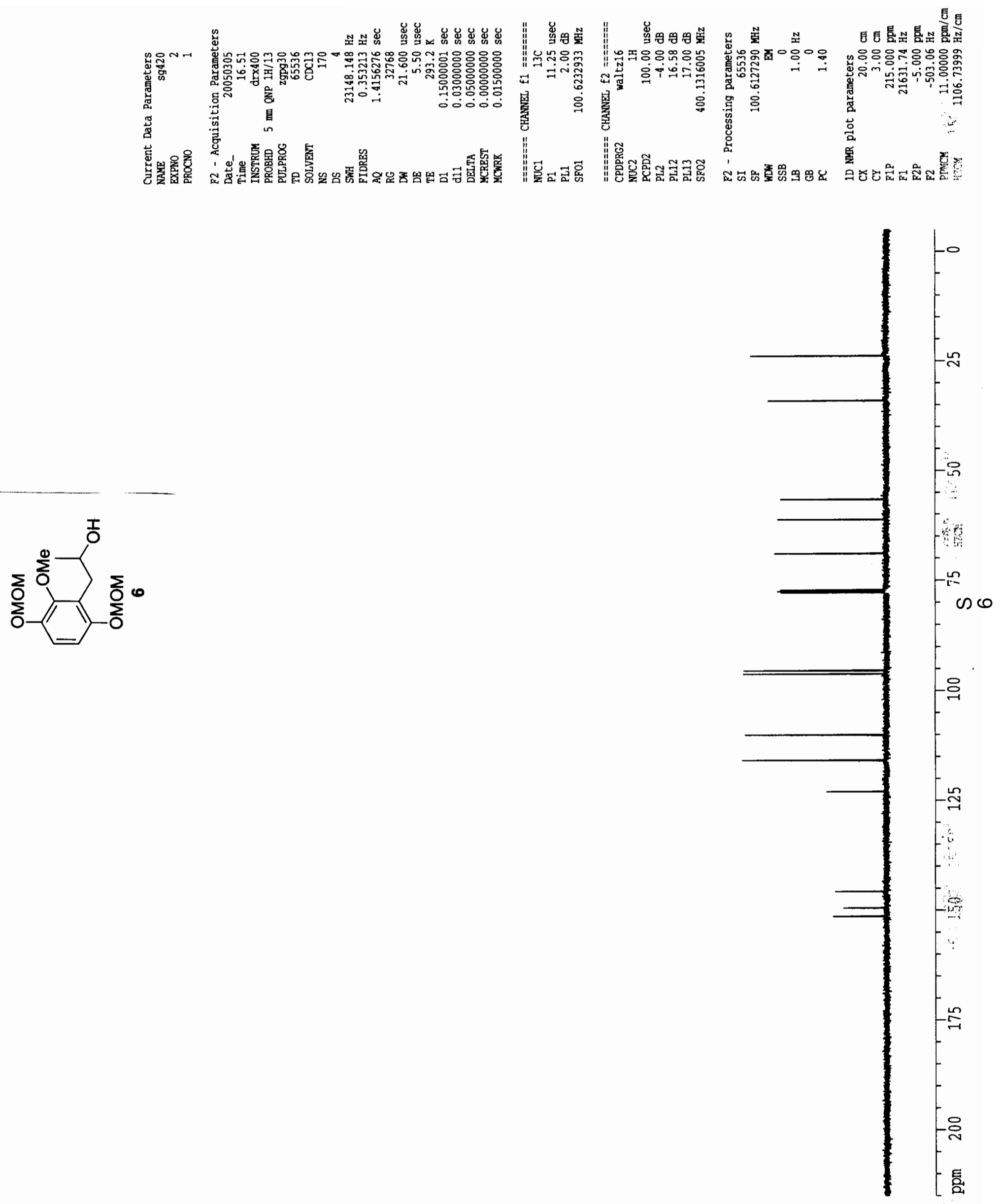

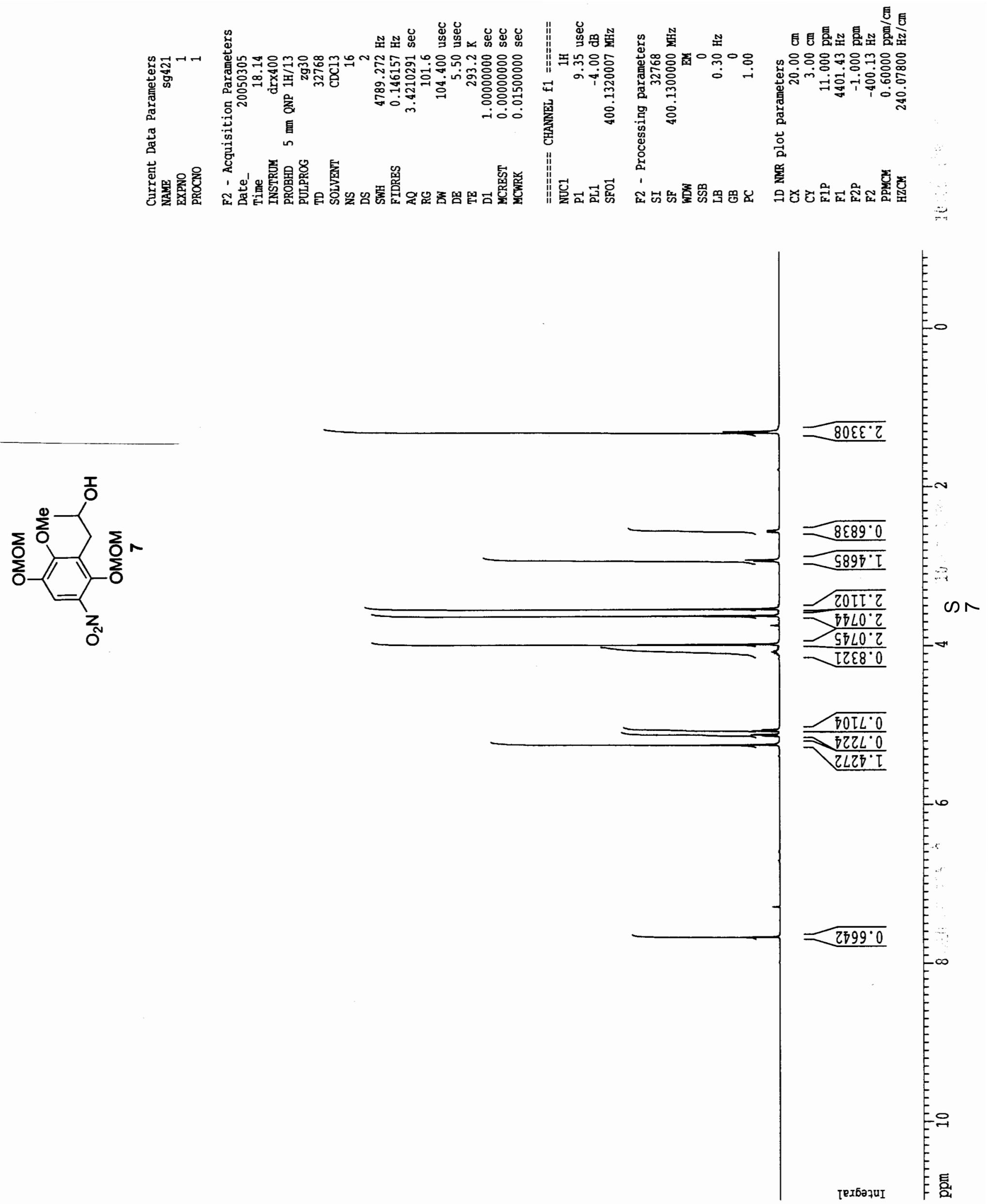

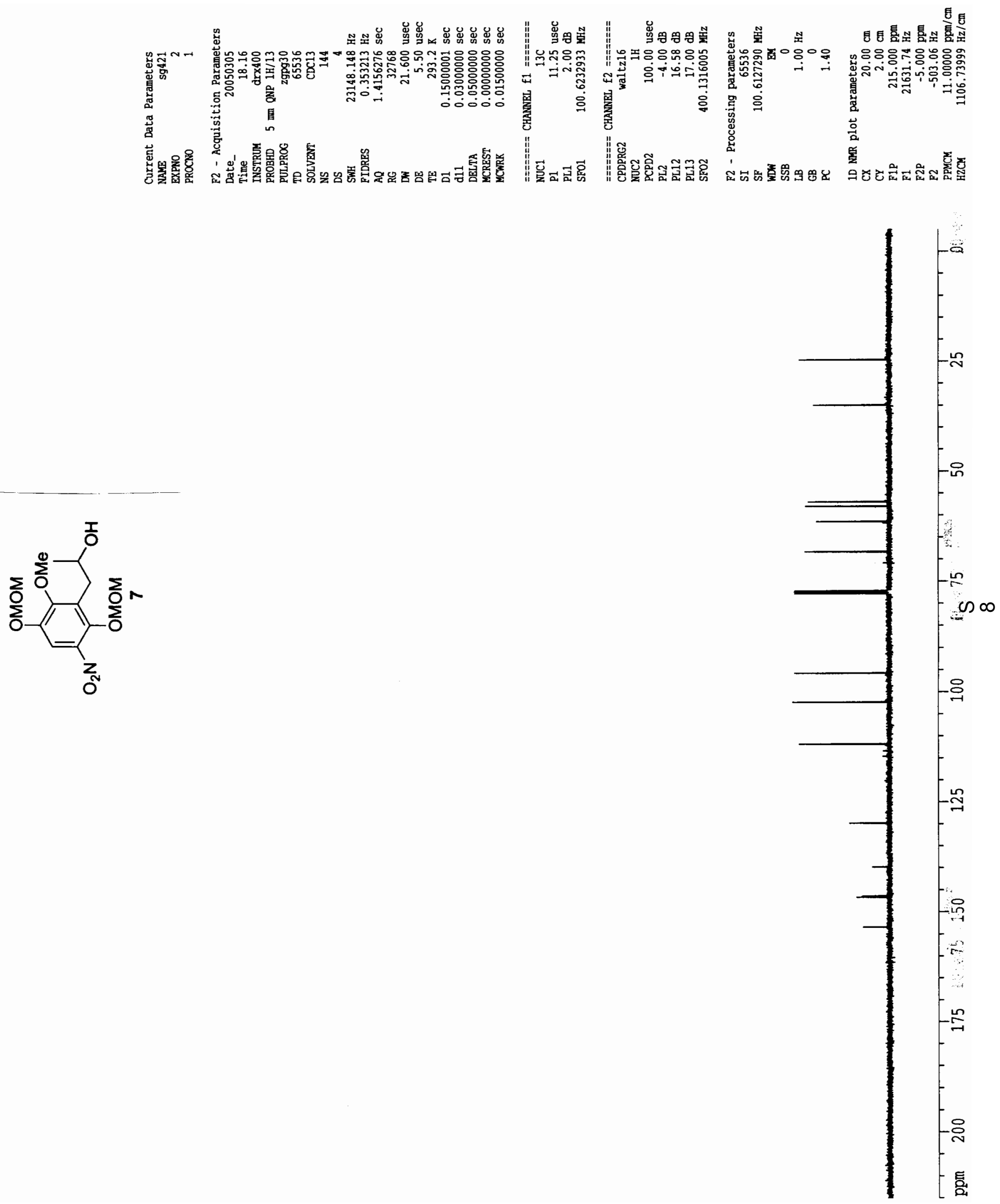

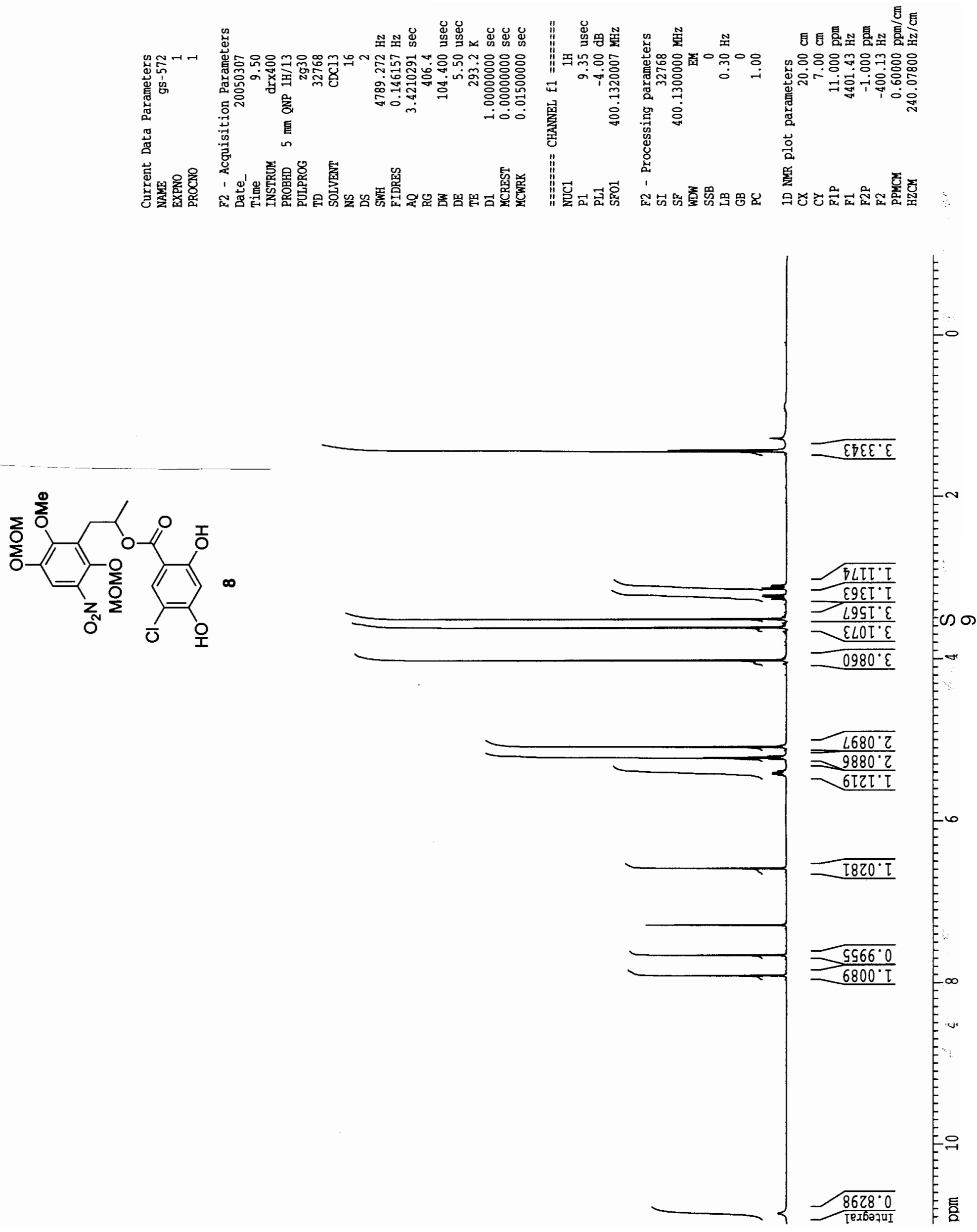

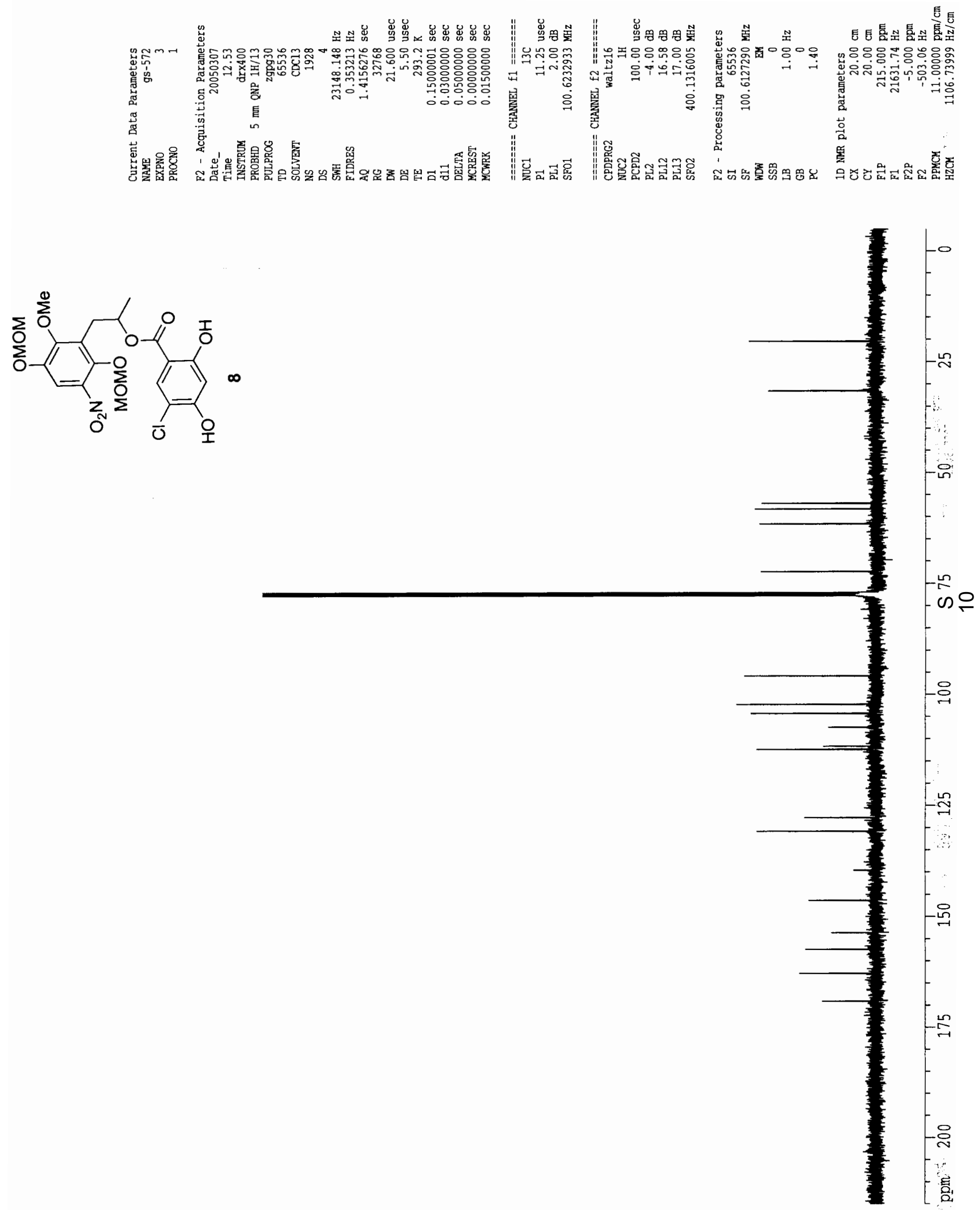

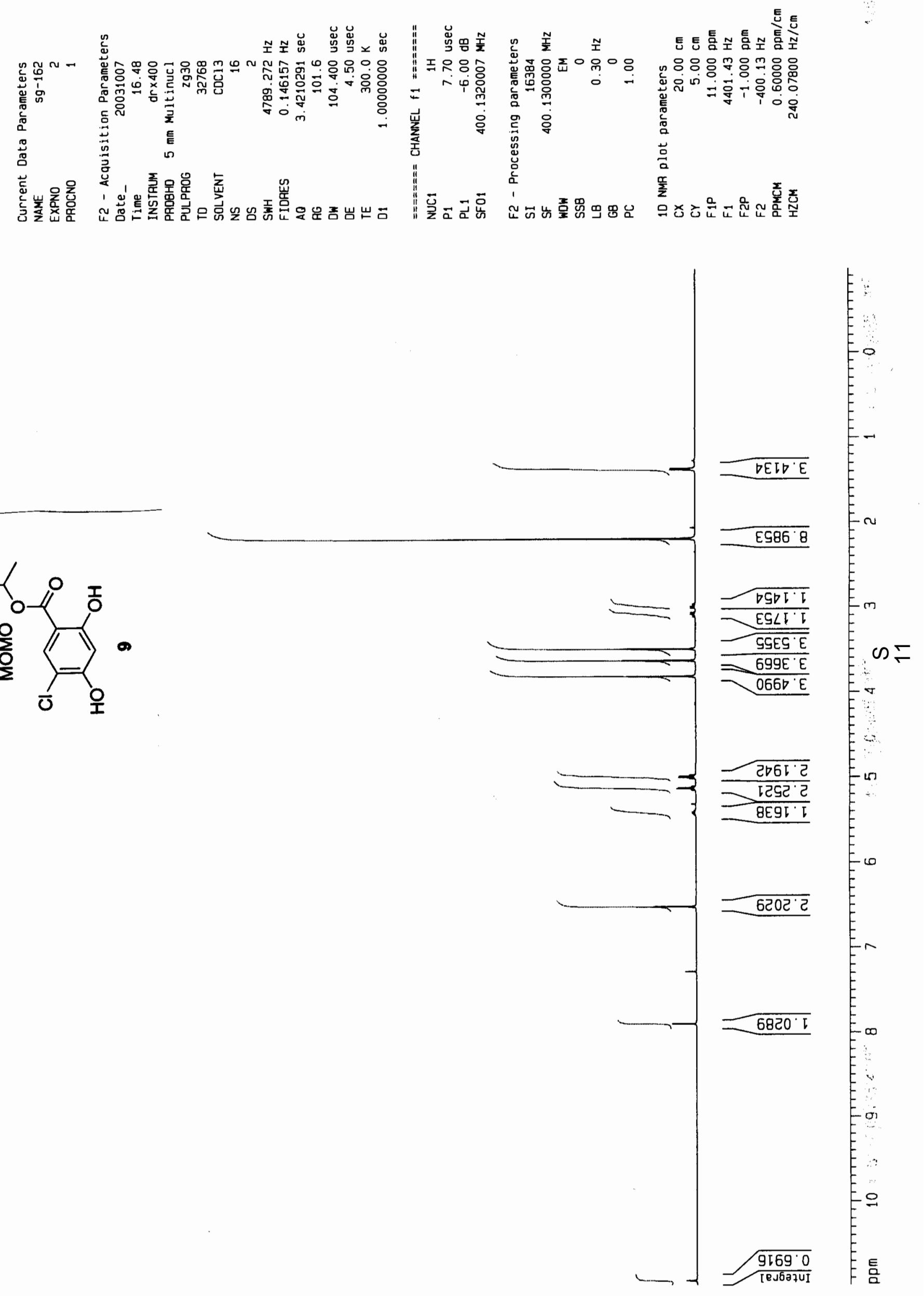

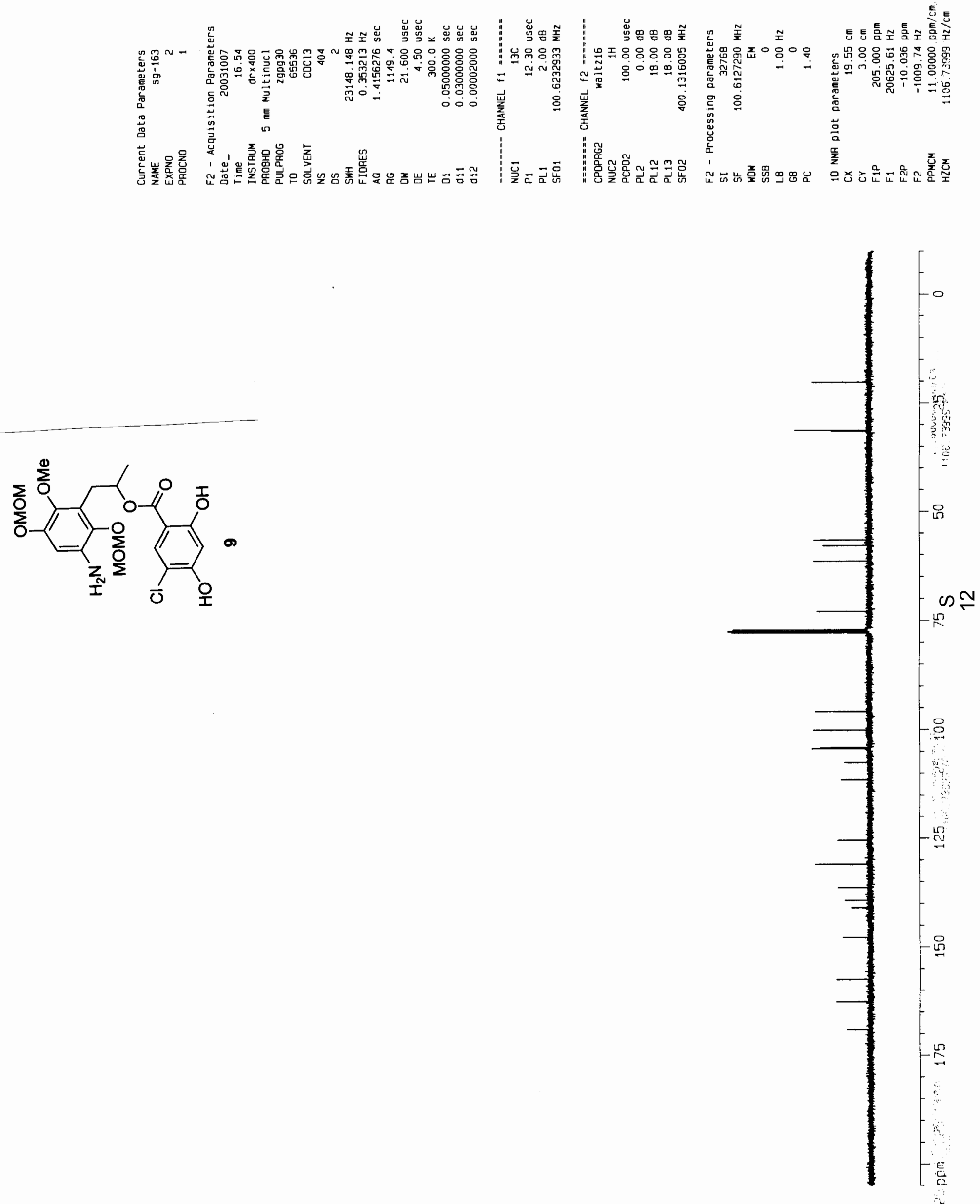

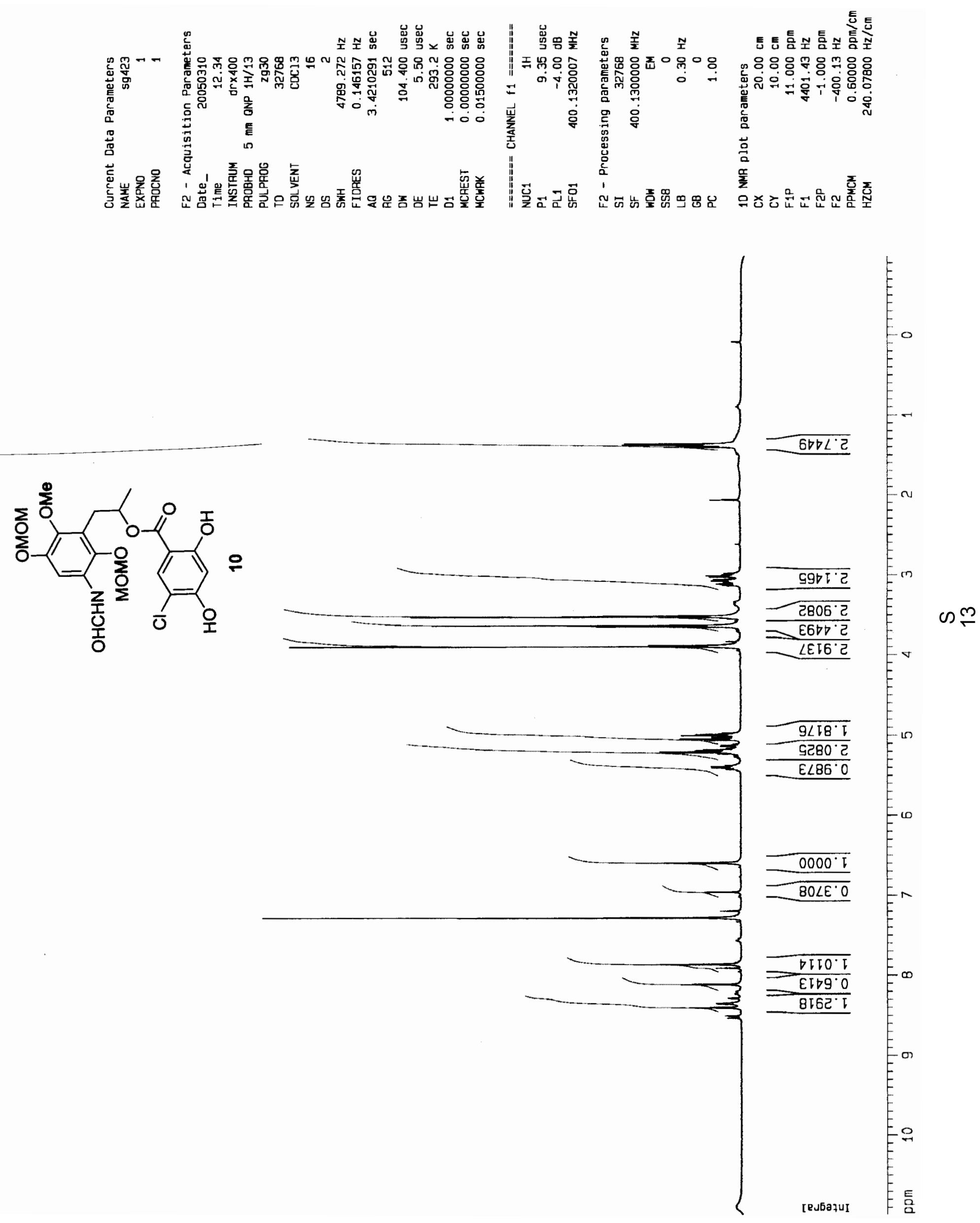


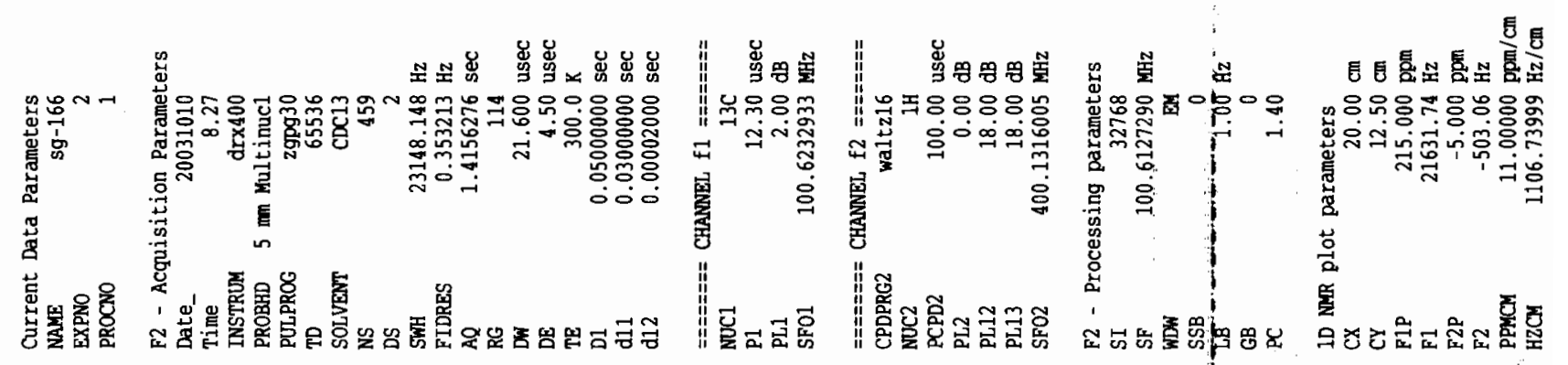

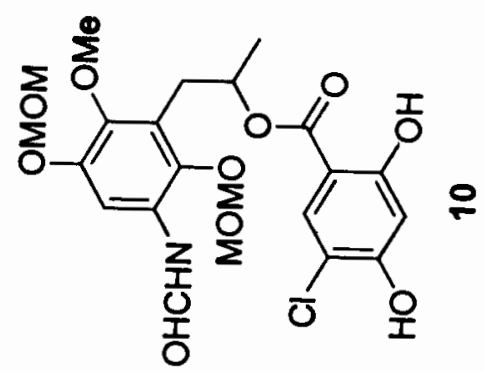



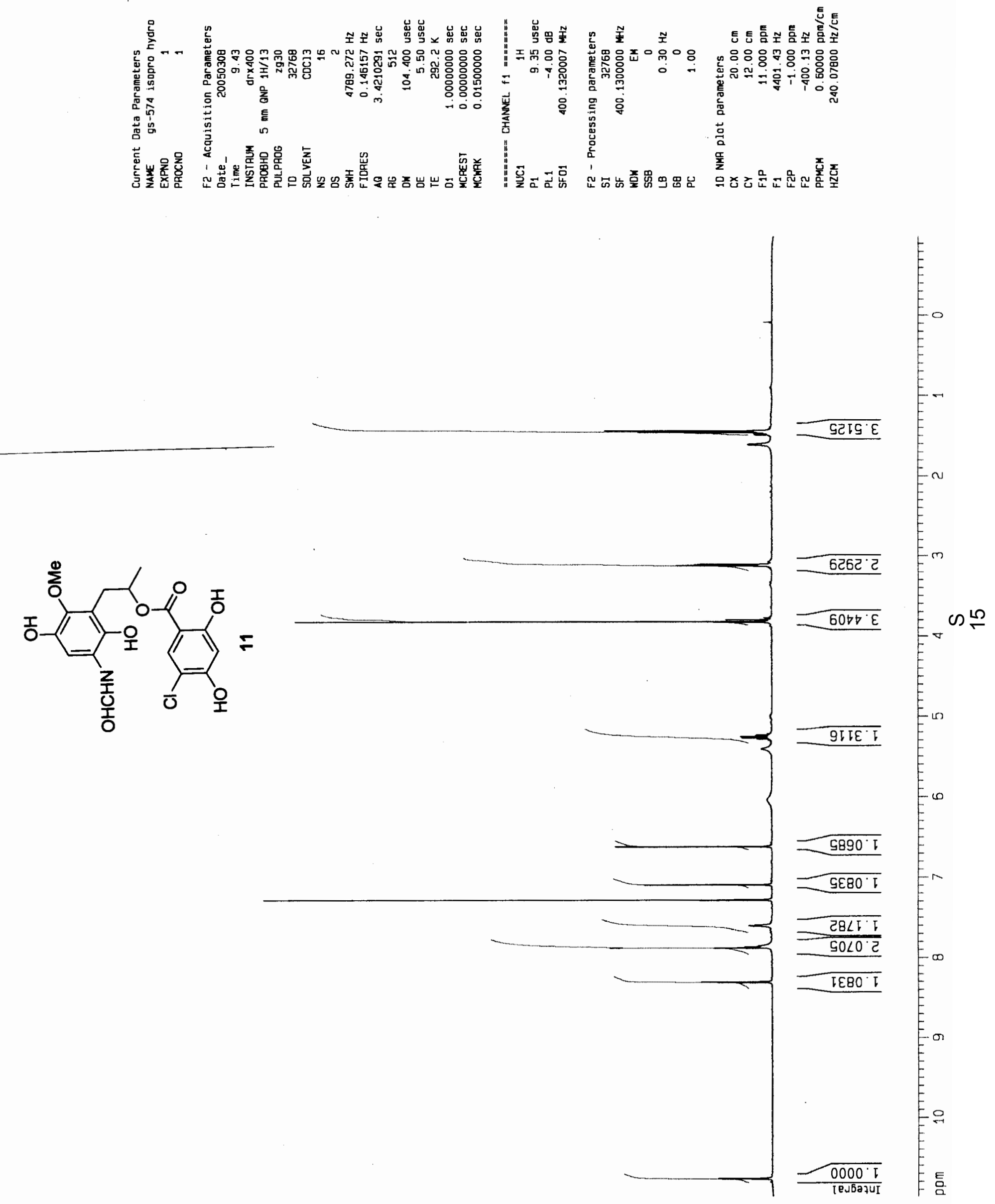


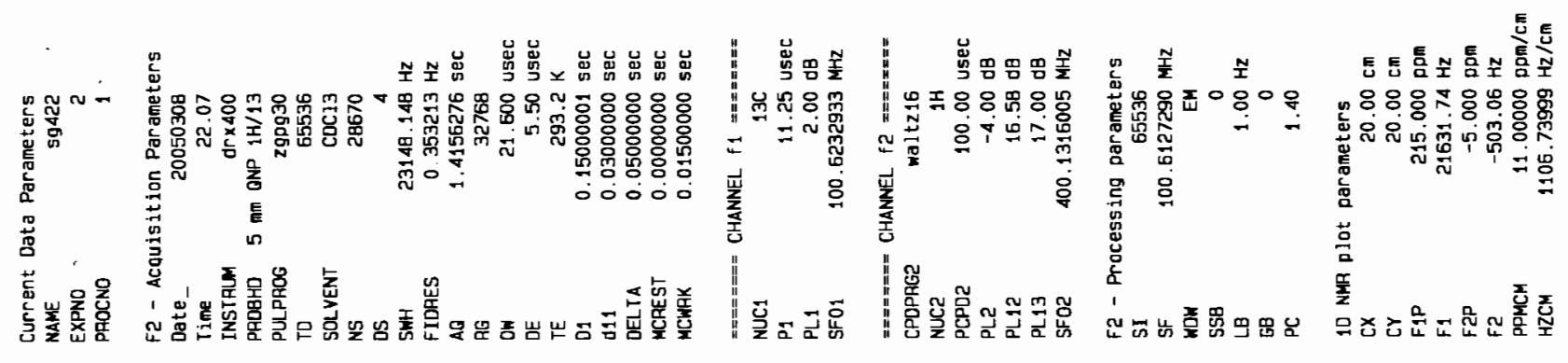
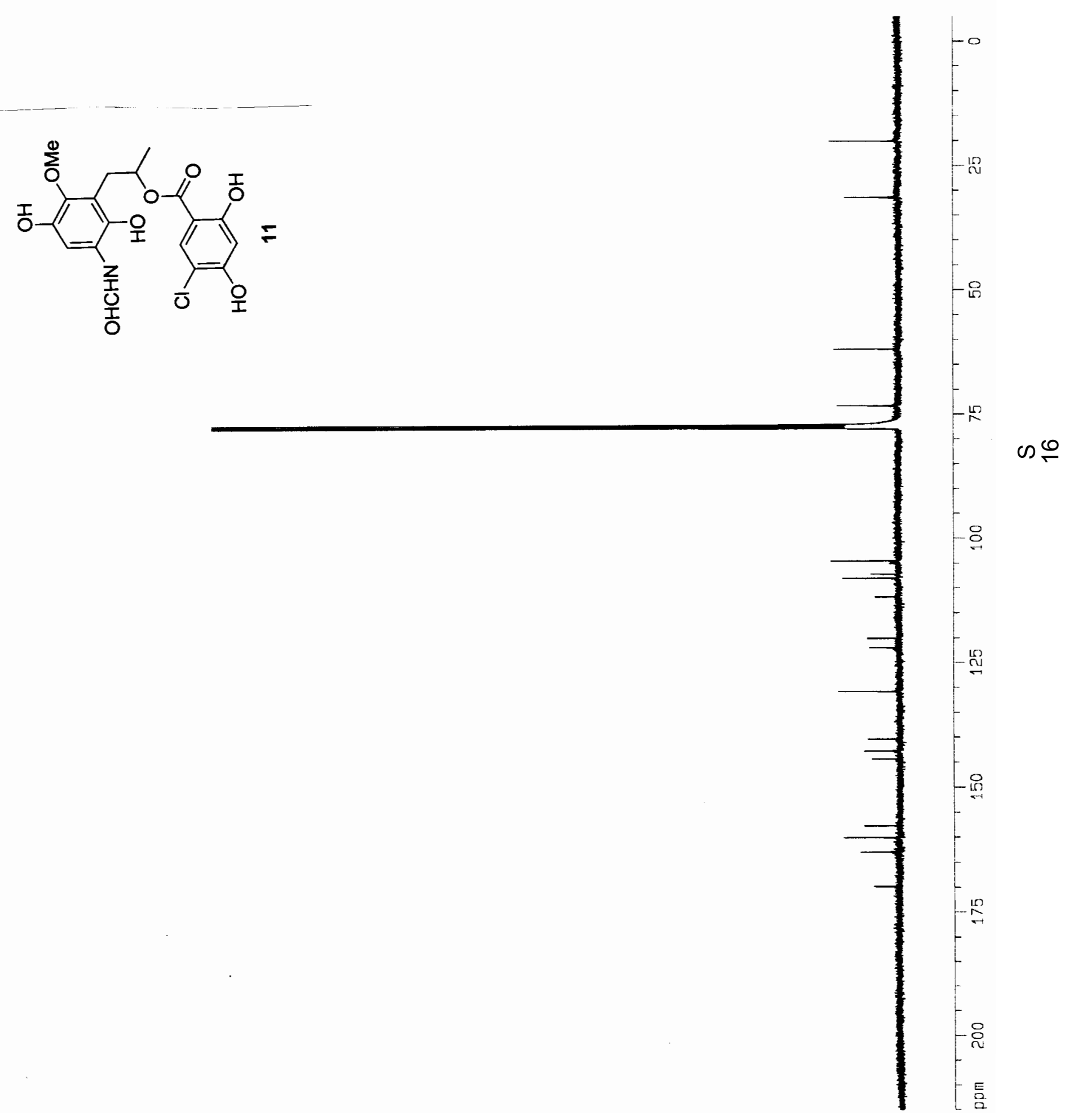

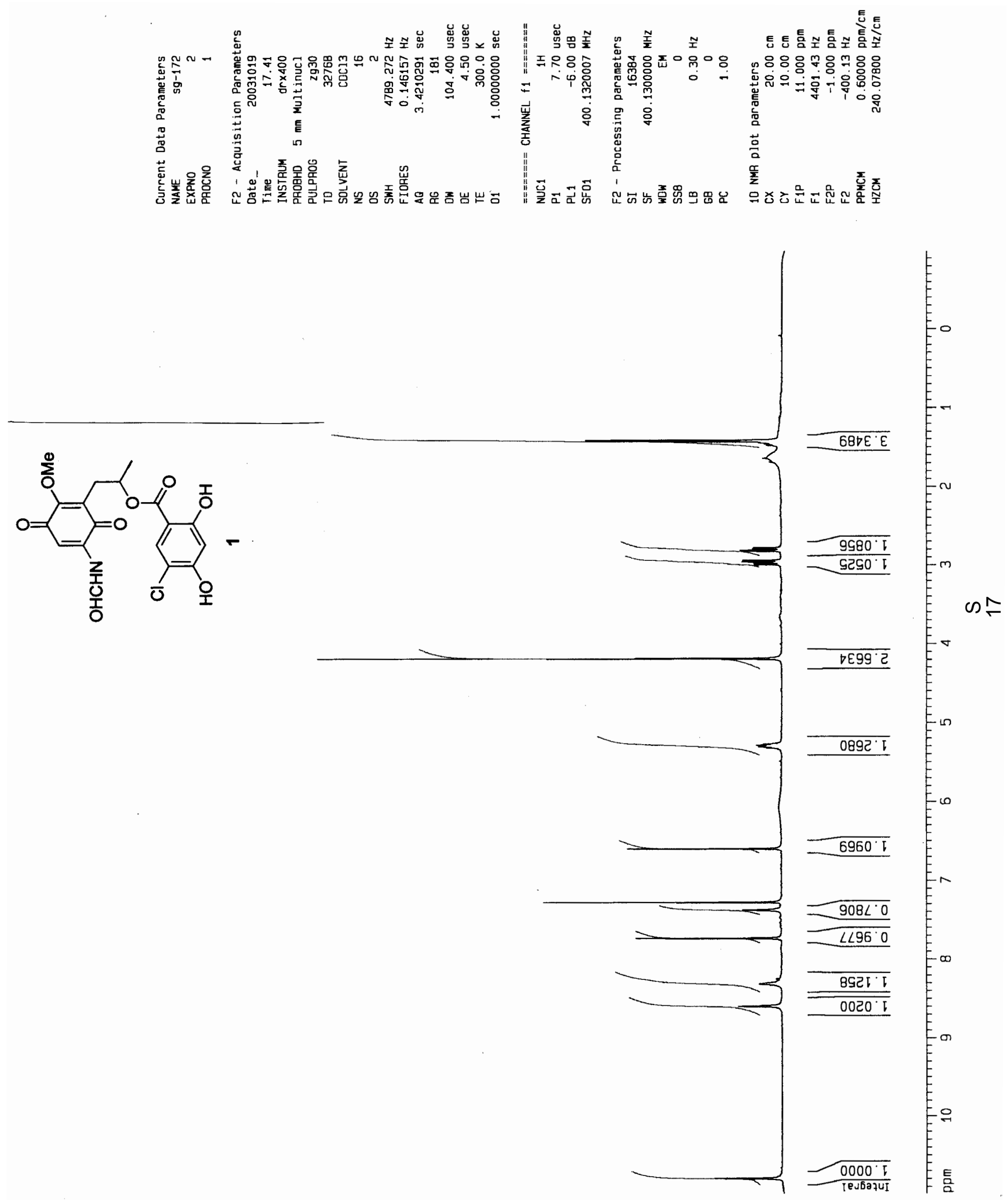

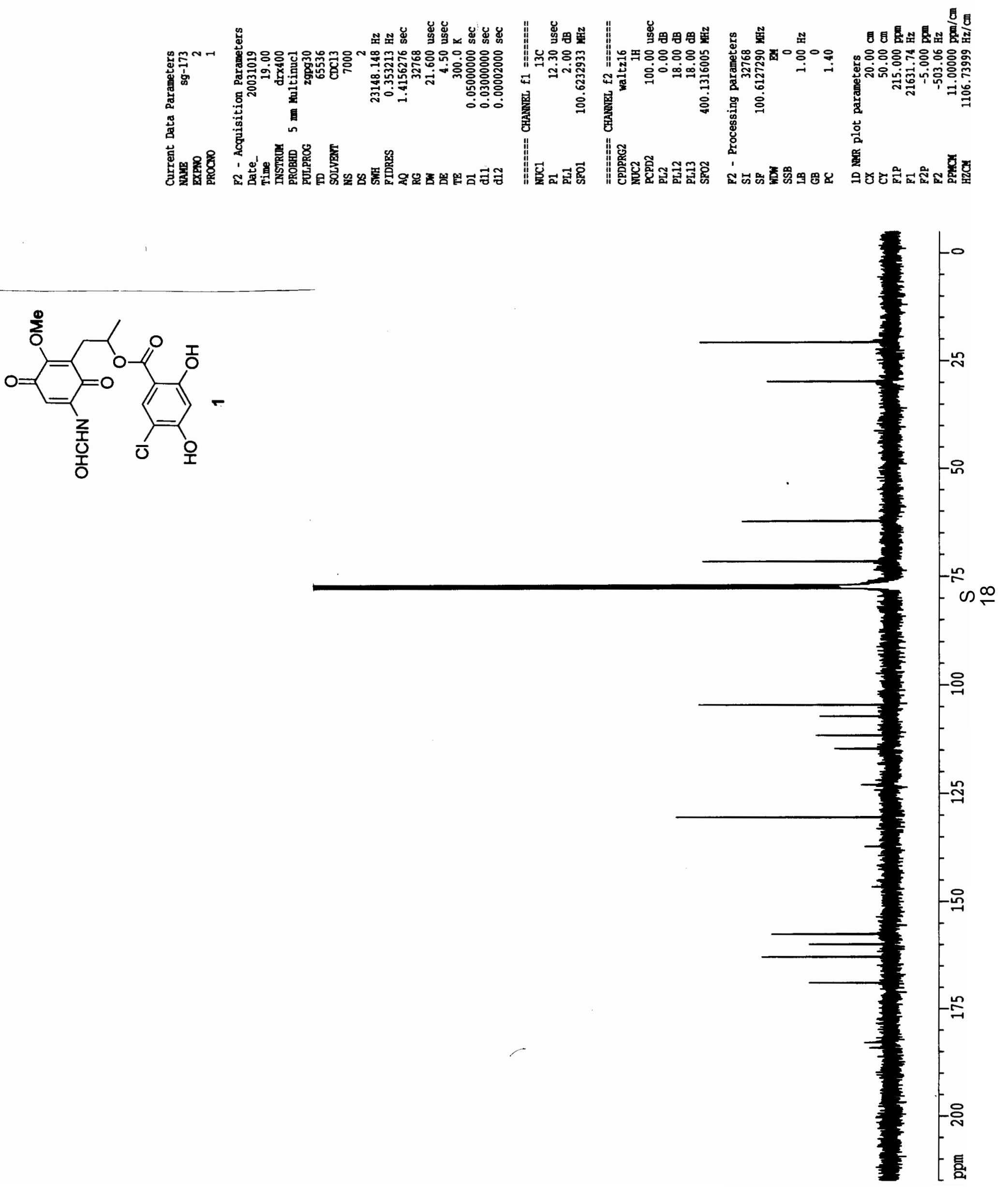